\title{
循環系の集中回路モデルと心収縮機能の検討
}

\author{
学生員 伊藤 満代* 正 員 小矢 美晴* \\ 正 員 溝尻 勳*
}

\section{Examination of Ventricular Contraction Function Using Electrical Lumped Circuit Model of Circulation System}

Mitsuyo Ito*, Student Member, Yoshiharu Koya*, Member, Isao Mizoshiri*, Member

\begin{abstract}
Presently, many of the already proposed blood circulation models are mainly partial models although they are precise models. A complete model that is a combination of these partial models are difficult to analyze because it is complicated to consider both the viscosity of blood and circulatory details at the same time. So, it is difficult to control the model parameters in order to adapt to various cases of circulatory diseases.

This paper proposes a complete circulation model as a lumped electrical circuit, which is comparatively simple. In the circuit model, total blood is modeled as seven lumped capacitors, representing the functions of atriums, ventricles, arteries, veins and lungs. We regard the variation of the ventricle capacitance as the driving force of the complete circulation model. In our model, we considered only the variation of pressure between each part and the blood capacity of each part.

In particular, the contraction function of the left ventricle is examined under the consideration of whole blood circulation.
\end{abstract}

キーワード : 回路モデル, 圧-容積関係, 心収縮機能

Keywords : circuit model, pressure-volume relation, ventricular contraction function

\section{1. まえがき}

循環系のモデル化と解析を行うことによって，体内にお ける血液循環の状態·各種病態の特徵決定が可能になり, 循 環系全体に対する訓練用ファントムの作成などが可能にな ると期待される(1)。その為, 循環系における様々な同定・解 析を用いて種々のモデルが提案されている(2)。しかし，それ らの多くは部分的なモデル表現であり，血液循環全体を考 慮したモデルは少ない(3)(4)。また，全体的なモデルでは，血 液の粘性や体内の細部にわたるモデルを考慮することで素 子が多く複雑となる為, 解析が困難である。

循環系全体に対する訓練用ファントムにおいて数值的解 析を行えることが望ましく，それに伴いモデルの簡単化が 求められる為, 従来提案されているモデルは有用性に欠ける。

一方, 部分的なモデルはその対象部分の入出力特性から 決定されている為に，比較的モデルが簡単化されている。 また，左心室のモデルは，大きく分けて三種類の手法が提

$*$ 立命館大学 理工学部 電気電子工学科

于525-8577 滋賀県草津市野路東 1-1-1

Department of Electrical and Electronic Engineering, Ritsumeikan University

1-1-1, Noji Higashi, Kusatsu, Shiga 525-8577
案されている。

(1)心筋線維個々の力学的特性に基づいて球状・円柱状・楕 円状の心室形状を仮定し, 圧・容積(張力-長さ)関係を解析し たシミュレーションモデル(5)。これは, 心室の形状・壁厚・ 心筋線維分布の方向性・心室局所における心筋の動作特性 の相違など多くの仮定を設けなければならず，またそのシ ミュレーションも複雑である。

(2)In Vitro, In Vivoの実験結果に基づき, あらかじめモ デルを仮定し諸変数を算出したモデル(6)。この場合, 通常心 室は時変型弾性として表現される。これは, 比較的単純で はあるが，循環系を一つのシステムとして大局的にとらえ る事ができる。

(3)心室の挙動をポンプ力学的に解釈し定電流源・定電圧 源とみなし，更に内部インピーダンスを仮定したモデル(7)。 これは, 心臓の拍動性を無視した, 平均心内圧-拍出量の関 係から導出されたものである。

これらの簡単な部分的モデルのみを用いて血液循環全体 をモデル化することは可能であるが，複合することによる 複雑さが伴い解析が困難となる。

そこで本研究では, 比較的単純で且つ大局的にとらえる 
ことのできる(2)の左心室モデルの手法を模して，血液循環 全体の回路を提案する。回路は，血液循環全体を 2 心房 2 心室と動脈, 静脈, 肺の 7 つに集中させ, 各部位間の圧降 下と各部位の容量性のみを考慮し簡単化する。更に, 採取 された左心室圧・容積データを本モデルに適用し，血液循環 全体を考慮した心収縮機能の検討を行う。

\section{2. 回路モデルとパラメータ推定}

〈2·1〉集中回路モデル ヒトの血液循環全体を 2 心 房 2 心室と動脈, 静脈, 肺の 7 つの集中的要素から構成し, 各部位間の圧降下と各部位の容量性のみを考慮することに より, 血液循環路が左心室 $\rightarrow$ 動脈 $\rightarrow$ 静脈 $\rightarrow$ 右心房 $\rightarrow$ 右心室 $\rightarrow$ 肺 $\rightarrow$ 左心房 $\rightarrow$ 左心室 ${ }^{(8)}$ となる簡単な集中回路モデルを提 案した(図 1)。尚, 回路モデルにおける各素子の記号一覧を 表 1 に示す。

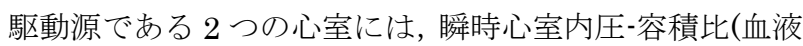
容量)を考慮し, 時変となる可変コンデンサ $C_{L V}(t), C_{R V}(t)$ を 用いた。血液は, この血液容量の変動と弁の開閉により拍 出・流入が行われている(9)(10)。尚, 血液の拍出・流入部に備 わっている弁の働きにはスイッチを用いて，血液循環の状 態を表現した。更に，心房一心室間には内圧変動を及ぼす弁 抵抗 $r$ を，心房の容量性にコンデンサ $C$ を用いた(11)。

これに対し血管系は大動脈-細動脈間を動脈，末梢血管大静脈間を静脈とし, 肺は肺循環全体を 1 つの要素に集中 化して，各部位間の圧降下を及ぼす素子に抵抗 $R$, 各部位 の容量性を表す素子にコンデンサ $C$ を用いた ${ }^{(11)}$ 。更に，体 循環動脈一体循環静脈間及び体循環静脈一右心房間におい て, 生体中で血液の逆流は生じない事より, ダイオードを 用いてこれを表現した。尚，本モデルにおいて，ダイオー ドの有無は解析上問題視しない。

ここで, 駆動源となる $C_{L V}(t), C_{R V}(t)$ 以外の素子は, 受動 的作用のみと考え心室のような能動的作用はないとして,

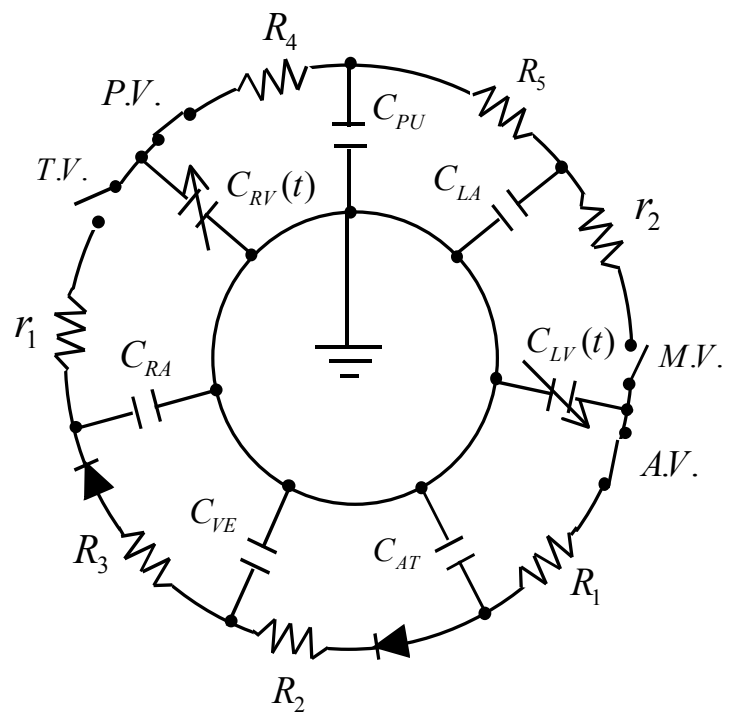

図 1 集中回路モデル

Fig. 1. Electrical lumped circuit model.
時間や内圧には依存しない一定值とした。

〈2·2〉 パラメータの定義 図 1 に示した循環系の集 中回路モデルの駆動源は, ある時刻 $t$ における血液容量 $C_{L V}(t), C_{R V}(t)$ によって生じる心室内圧 $v_{L V}(t), v_{R V}(t)$ であ る。この時, 流れる血流量を $i_{L V}(t), i_{R V}(t)$ とする。また, 駆 動源を除く各部位では $v_{L V}(t), v_{R V}(t)$ の作用により血液が流 れ $(i(t))$, 内圧 $(v(t))$ が生じる。更に, 電気回路の特性と血

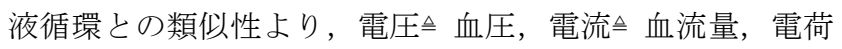
量血液量とすると, 各部位における係数 $C_{A T, \cdots, L A}, R_{1-5}, r_{1,2}$ は 次式で定義できる。

$$
\left\{\begin{array}{l}
C_{A T, \cdots, L A}[\mathrm{ml} / \mathrm{mmHg}]=\frac{Q_{\text {min }}}{V_{\text {mean }}} \\
R_{1-5}[\mathrm{mmHg} \cdot \mathrm{sec} / \mathrm{ml}]=r_{1,2}=\frac{V_{d-\text { mean }}}{S V / T_{\text {time }}}
\end{array}\right.
$$

$Q_{\text {min }}[m l]$ : 貯蓄血液量, $V_{\text {mean }}[\mathrm{mmHg}]$ : 一周期平均圧

$V_{d-\text { mean }}[\mathrm{mmHg}]$ : 部位間圧差の平均, $S V[\mathrm{ml}]$ : 一回拍出量 また, 各部位の血圧変化は式(2)(3)の連立微分方程式によ って表現される。

ここで式(1)の $T_{\text {time }}$ は, 心室におけるスイッチの開閉(時相) によって作用する抵抗(作用抵抗)が異なるため, 各抵抗の作 用時間を用いる。尚, 各時相条件(12) とスイッチの状態, 作 用抵抗は表 2 に示す通りである。表 2 より, 心室収縮期で は $L A-L V$ 間・ $R A-R V$ 間に血液は流れず(2)(4)(6)(8)の項 が，拡張期では $L V-A T$ 間・ $R V-P U$ 間に血液は流れず(1) (3)(5)(7)の項が，等容収縮・弛緩期においては(1)〜 (8)の項が 0 となる。

表 1 各素子の記号一覧

Table 1. List of elements.

\begin{tabular}{|c||c|}
\hline Symbol & Name of symbol \\
\hline \hline$C_{L V}(t)$ & Equivalent Capacitance to Left Ventricle \\
\hline$C_{A T}$ & Equivalent Capacitance to Artery in Body Circulation \\
\hline$C_{V E}$ & Equivalent Capacitance to Vein in Body Circulation \\
\hline$C_{R A}$ & Equivalent Capacitance to Right Atrium \\
\hline$C_{R V}(t)$ & Equivalent Capacitance to Right Ventricle \\
\hline$C_{P U}$ & Equivalent Capacitance to Vessel in Pulmonary \\
\hline$C_{L A}$ & Equivalent Capacitance to Left Atrium \\
\hline$R_{1}$ & Resistance by Blood Viscosity of Artery in Body Circulation \\
\hline$R_{2}$ & Resistance by Blood Viscosity of Capillary in Body \\
\hline$R_{3}$ & Circulation \\
\hline$R_{4}$ & Resistance by Blood Viscosity of Vein in Body Circulation \\
\hline$R_{5}$ & Resistance by Blood Viscosity of Artery in Pulmonary \\
\hline$r_{1}$ & Orificial resistance of Tricuspid Valve \\
\hline$r_{2}$ & Orificial resistance of Mitral Valve \\
\hline$A . V$. & Aortic Valve \\
\hline$M . V$. & Mitral Valve \\
\hline$T . V$. & Tricuspid Valve \\
\hline$P . V$. & Pulmonic Valve \\
\hline & \\
\hline & \\
\hline & \\
\hline
\end{tabular}


表 2 時相の条件とスイッチの状態及び作用抵抗

Table 2. The conditions of time intervals, and the state of switch and action resistance.

\begin{tabular}{|c|c|c|c|c|c|}
\hline & & systole & isovolumic relaxation & diastole & isovolumic contraction \\
\hline \multirow{4}{*}{ 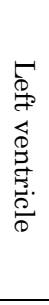 } & condition & $\left\{\begin{array}{c}v_{L V}(t)>v_{A T}(t) \\
\text { and } \\
v_{L V}(t)>v_{L A}(t)\end{array}\right.$ & $\left\{\begin{array}{c}v_{L V}(t) \leq v_{A T}(t) \\
\text { and } \\
v_{L V}(t)>v_{L A}(t)\end{array}\right.$ & $\left\{\begin{array}{c}v_{L V}(t)<v_{A T}(t) \\
\text { and } \\
v_{L V}(t)<v_{L A}(t)\end{array}\right.$ & $\left\{\begin{array}{c}v_{L V}(t)<v_{A T}(t) \\
\text { and } \\
v_{L V}(t) \geq v_{L A}(t)\end{array}\right.$ \\
\hline & A.V. & $\mathrm{ON}$ & $\mathrm{OFF}$ & $\mathrm{OFF}$ & $\mathrm{OFF}$ \\
\hline & $M . V$. & $\mathrm{OFF}$ & $\mathrm{OFF}$ & $\mathrm{ON}$ & OFF \\
\hline & $\begin{array}{l}\text { action } \\
\text { resistance }\end{array}$ & $R_{1}, R_{2}, R_{3}$ & $R_{2}, R_{3}$ & $R_{5}, r_{2}$, & $R_{5}$ \\
\hline \multirow{4}{*}{ 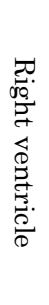 } & condition & $\left\{\begin{array}{c}v_{R V}(t)>v_{P U}(t) \\
\text { and } \\
v_{R V}(t)>v_{R A}(t)\end{array}\right.$ & $\begin{array}{c}v_{R V}(t) \leq v_{P U}(t) \\
\text { and } \\
v_{R V}(t)>v_{R A}(t)\end{array}$ & $\left\{\begin{array}{c}v_{R V}(t)<v_{P U}(t) \\
\text { and } \\
v_{R V}(t)<v_{R A}(t)\end{array}\right.$ & $\left\{\begin{array}{c}v_{R V}(t)<v_{P U}(t) \\
\text { and } \\
v_{R V}(t) \geq v_{R A}(t)\end{array}\right.$ \\
\hline & $P . V$. & $\mathrm{ON}$ & $\mathrm{OFF}$ & OFF & OFF \\
\hline & T.V. & OFF & $\mathrm{OFF}$ & $\mathrm{ON}$ & OFF \\
\hline & $\begin{array}{l}\text { action } \\
\text { resistance }\end{array}$ & $R_{4}, R_{5}$ & $R_{5}$ & $R_{2}, R_{3}, r_{1}$ & $R_{2}, R_{3}$ \\
\hline
\end{tabular}

$$
\begin{aligned}
& i_{L V}(t)=v_{L V}(t) \frac{d C_{L V}(t)}{d t}+C_{L V}(t) \frac{d v_{L V}(t)}{d t} \\
& =-(\underbrace{i_{A T}+i_{V E}+i_{R A}}_{\text {(1) }}+\underbrace{i_{P U}+i_{L A}}_{(2)}) \\
& i_{R V}(t)=v_{R V}(t) \frac{d C_{R V}(t)}{d t}+C_{R V}(t) \frac{d v_{R V}(t)}{d t} \\
& =-(\underbrace{i_{P U}+i_{L A}}_{\text {(3) }}+\underbrace{i_{A T}+i_{V E}+i_{R A}}_{\text {(4) }}) \\
& \left\{\begin{aligned}
i_{A T}(t) & =C_{A T} \frac{d v_{A T}(t)}{d t} \\
& =-\frac{v_{A T}(t)-v_{V E}(t)}{R_{2}} \underbrace{-v_{A T}(t)-v_{L V}(t)}_{(5)}
\end{aligned}\right. \\
& i_{V E}(t)=C_{V E} \frac{d v_{V E}(t)}{d t} \\
& =-\frac{v_{V E}(t)-v_{R A}(t)}{R_{3}}-\frac{v_{V E}(t)-v_{A T}(t)}{R_{2}} \\
& i_{R A}(t)=C_{R A} \frac{d v_{R A}(t)}{d t} \\
& =\underbrace{-\frac{v_{R A}(t)-v_{R V}(t)}{r_{1}}}-\frac{v_{R A}(t)-v_{V E}(t)}{R_{3}} \\
& i_{P U}(t)=C_{P U} \frac{d v_{P U}(t)}{d t}
\end{aligned}
$$

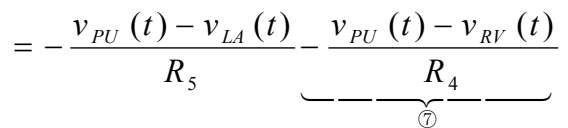

$$
\begin{aligned}
& i_{L A}(t)=C_{L A} \frac{d v_{L A}(t)}{d t} \\
& =\underbrace{-\frac{v_{L A}(t)-v_{L V}(t)}{r_{2}}-}_{8}-\frac{v_{L A}(t)-v_{P U}(t)}{R_{5}}
\end{aligned}
$$

〈2·3〉 パラメータ推定＼cjkstart各部位の血液容量は以下の 二つの条件を満たすように決定する。尚, 各部位間での粘 性抵抗及び弁抵抗 $R_{1-5}, r_{1,2}$ は, 以下に示寸条件の影響を受け ず一定とし, 医学的に示されている各部位の平均データ及 び臨床により得られた各症例の心拍時間を用いて, 式(1)に より算出した值を最適值とする。

（条件 1）一心拍時間は常に一定

（条件 2）各部位の血圧・血流量は心一周期において周期的 一心拍時間を一定として血液容量 $C_{L V}(t), C_{R V}(t)$ に対し, 各部位の血圧・血流量が周期的となるよう各部位の血液容 量 $C_{A T, \cdots, L A}$ を決定する。尚, 左心室における血液容量 $C_{L V}(t)$ は, 臨床により得られた左心室圧 $P_{L V}(t)$ 及び左心室血液量 $V_{L V}(t)$ を用いて, 式(4)により算出したものである。また, 右心室については, 臨床的にデータを採取することが困難 なため, 左心室と同相かつ相似な変化と仮定し, 医学的に 示されている左心室と右心室の平均的比率により $C_{L V}(t)$ を 定数倍したものを用いた。従って $C_{L V}(t), C_{R V}(t)$ は, 用いる 症例や状態によりに異なる周期データである。

$$
C_{L V}(t)=V_{L V}(t) / P_{L V}(t)
$$

ここで, 各部位における血圧・血流量の推定は，4 次の Runge-Kutta 法(13)を用いて式(2)(3)より求める。この時, 心 一周期(初期時間 : $T_{0} \sim$ 一心拍時間 : $T_{R R}$ )の血圧が周期的 $v\left(T_{0}\right) \cong v\left(T_{R R}\right)$ となる収束䛊差 $($ Error $)$ を定め, 収束するま で式(5)により初期值とパラメータ $C_{A T, \cdots, L A}$ の更新(図 2)を 行う。

$$
\left\{\begin{array}{l}
v^{\prime}\left(T_{0}\right)=\frac{v\left(T_{0}\right)+v\left(T_{R R}\right)}{2} \\
C_{A T, \cdots, L A}=\frac{Q_{\min }}{\sum_{t=0}^{n-1} v(t) / n}
\end{array}\right.
$$




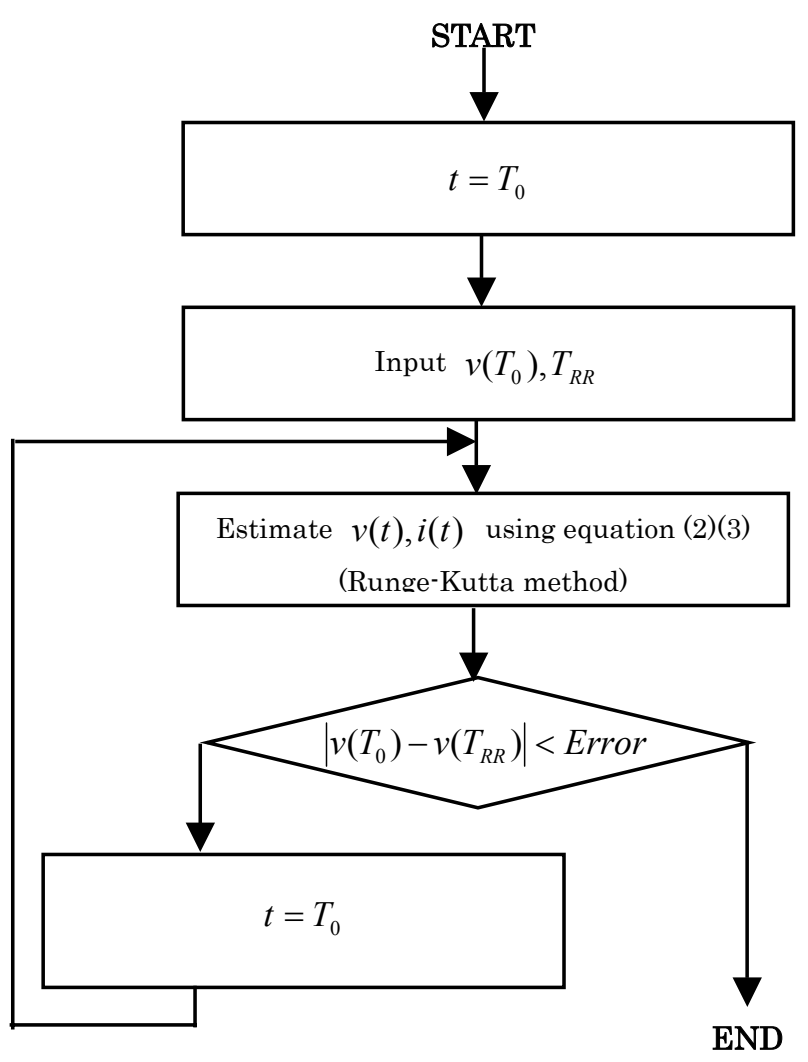

図 2 パラメータの最適化法フローチャート

Fig. 2. Flowchart of parameter estimation.

表 3 推定パラメータ

Table 3. Estimated parameter.

\begin{tabular}{|c||c|c|}
\hline & Normal & $\begin{array}{c}\text { Dilated } \\
\text { cardiomyopathy }\end{array}$ \\
\hline \hline$R_{1}[\mathrm{mmHg} \cdot \mathrm{s} / \mathrm{ml}]$ & 0.2123 & 0.2355 \\
\hline$R_{2}[\mathrm{mmHg} \cdot \mathrm{s} / \mathrm{ml}]$ & 0.6589 & 0.8079 \\
\hline$R_{3}[\mathrm{mmHg} \cdot \mathrm{s} / \mathrm{ml}]$ & 0.0051 & 0.0304 \\
\hline$R_{4}[\mathrm{mmHg} \cdot \mathrm{s} / \mathrm{ml}]$ & 0.0373 & 0.0450 \\
\hline$R_{5}[\mathrm{mmHg} \cdot \mathrm{s} / \mathrm{ml}]$ & 0.0811 & 0.0982 \\
\hline$r_{1}[\mathrm{mmHg} \cdot \mathrm{s} / \mathrm{ml}]$ & 0.0089 & 0.0108 \\
\hline$r_{2}[\mathrm{mmHg} \cdot \mathrm{s} / \mathrm{ml}]$ & 0.0099 & 0.0115 \\
\hline$C_{A T}[\mathrm{ml} / \mathrm{mmHg}]$ & 1.4900 & 17.582 \\
\hline$C_{V E}[\mathrm{ml} / \mathrm{mmHg}]$ & 102.302 & 889.385 \\
\hline$C_{R A}[\mathrm{ml} / \mathrm{mmHg}]$ & 2.015 & 24.388 \\
\hline$C_{P U}[\mathrm{ml} / \mathrm{mmHg}]$ & 3.022 & 36.175 \\
\hline$C_{L A}[\mathrm{ml} / \mathrm{mmHg}]$ & 0.772 & 8.612 \\
\hline
\end{tabular}

以上より得られたパラメータを表 3 に示す。また, 得ら れたパラメータを用いてシミュレーションを行った際に生 じた左心室圧と, 臨床において採取された左心室圧との比 較を図 3 に示す。尚, 図 3 中において実線が推定データ, 点線が臨床データである。

ここで, 表 3 に示したパラメータ值は, 回路モデルが周 期的となる為の唯一解であり, 心収縮機能の検討を行う際,

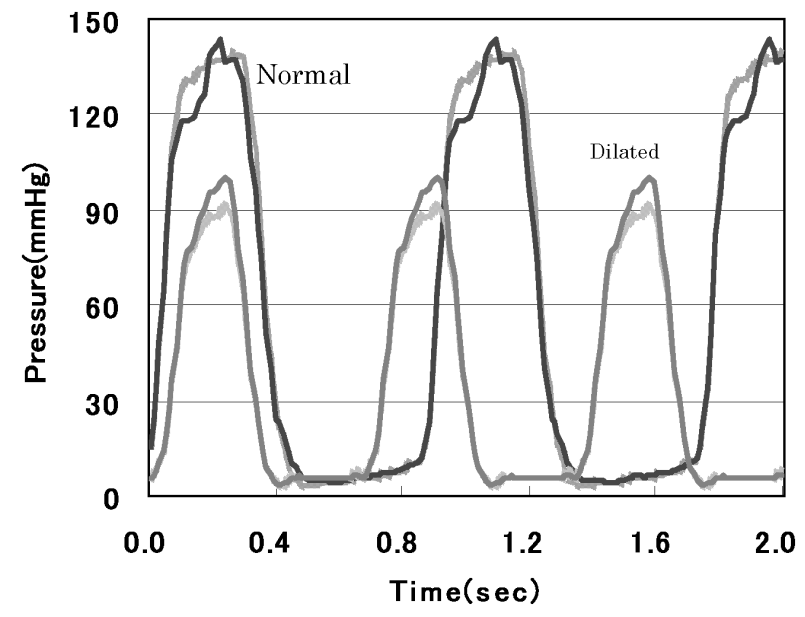

図 3 左心室圧の比較

Fig. 3. Waveforms of left ventricle pressure.

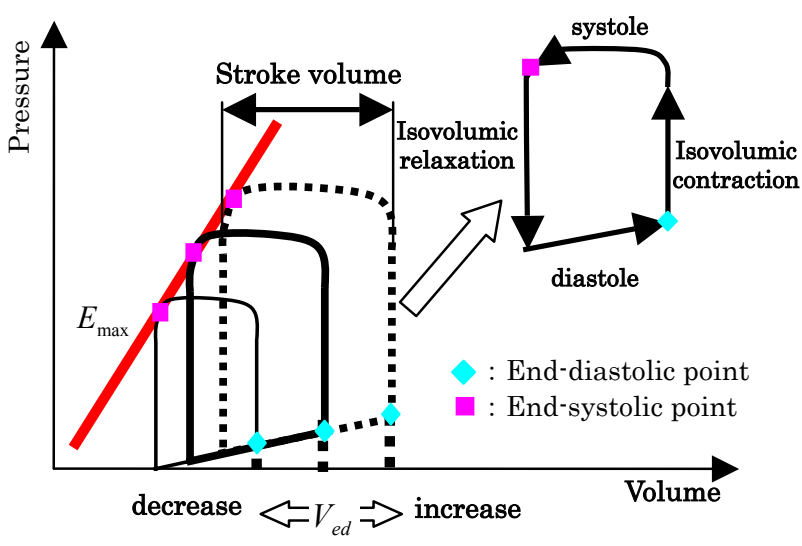

図 4 圧-容積曲線

Fig. 4. Pressure-volume relation.

負荷を変化させると, 各部位における血液容量は周期的と なるよう変化する。この時, 各部位間の抵抗は不変である。

\section{3. 心収縮機能の検討}

一般に心収縮機能の評価は, 人為的に心筋収縮開始前後 に心筇にかかる負荷(前負荷, 後負荷)を変化させて得られる 圧-容積曲線や，これにより得られる左心室の収縮末期 圧容積関係 $E_{\text {max }}$, 左心室駆出率 $E F$ により測ることがで きる(14)(15)。

本研究では，心収縮機能の評価を前負荷を用いて行う。

尚, $E_{\text {max }}$ は前負荷を変化させた際の各々の収縮末期点を 結んだ直線の傾き(図 4)で表され, 心収縮性が低いほど傾き は小さい(16)。また，EF は式(6)により定義されており, 正 常值は $0.58 \sim 0.89$ である(14)。

$$
E F=S V / V_{e d}
$$

$S V[m l]$ : 一回拍出量, $V_{e d}[m l]$ : 拡張末期容積 

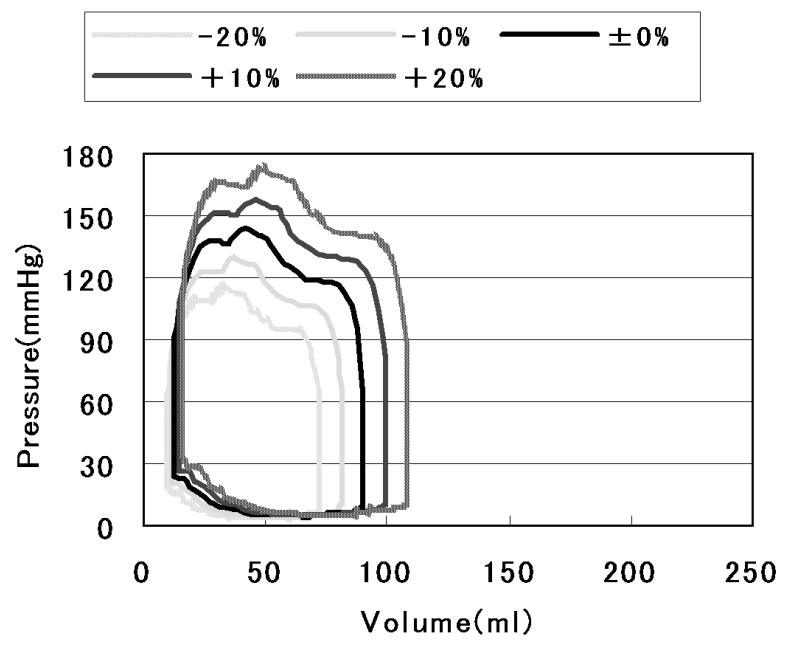

(a) 健常

(a) Normal
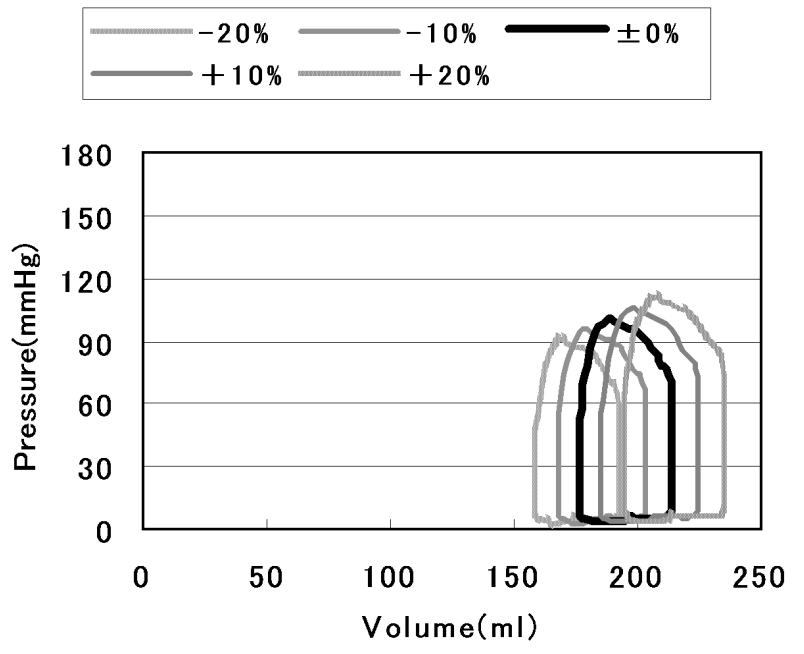

(b) 拡張型心筇症

(b) Dilated cardiomyopathy

図 5 前負荷を変化させた時の $\mathrm{P}-\mathrm{V}$ 曲線

Fig. 5. Change of pressure-volume relation by preload.

〈3.1〉 圧一容積関係 本モデルにおいて, 前負荷の パラメータに拡張末期容積 $V_{e d}$ を用いて, これを人為的に変 化させた時の圧一容積曲線を図 5 に示す。尚, $V_{e d}$ の変化範 囲は臨床により採取されたデータに対し $\pm 10 \% ， \pm 20 \%$ で 行った。

図 5 より, 前負荷を増加させると, 収縮末期圧が上昇し 圧-容積曲線は全体的に右上方へ移動することが示せた。ま た, 健常に比べて拡張型心筋症は, $V_{\text {ed }}$ の増加に伴った収縮 末期圧の上昇が少ないことが示せた。

$\langle 3 \cdot 2\rangle$ 収縮末期圧-容積関係 $E_{\max }$ 図 5 の結果より, 健常及び拡張型心筋症の各々の収縮末期点と $E_{\max }$ を図 6 に 示す。

図 6 より, 拡張型心筋症の $E_{\text {max }}$ は健常に比べ明らかに傾 きが小さく，心収縮性が低いことを示せた。更に，拡張型 心筋症では拡張末期容量の増加に対する圧の上昇が少ない

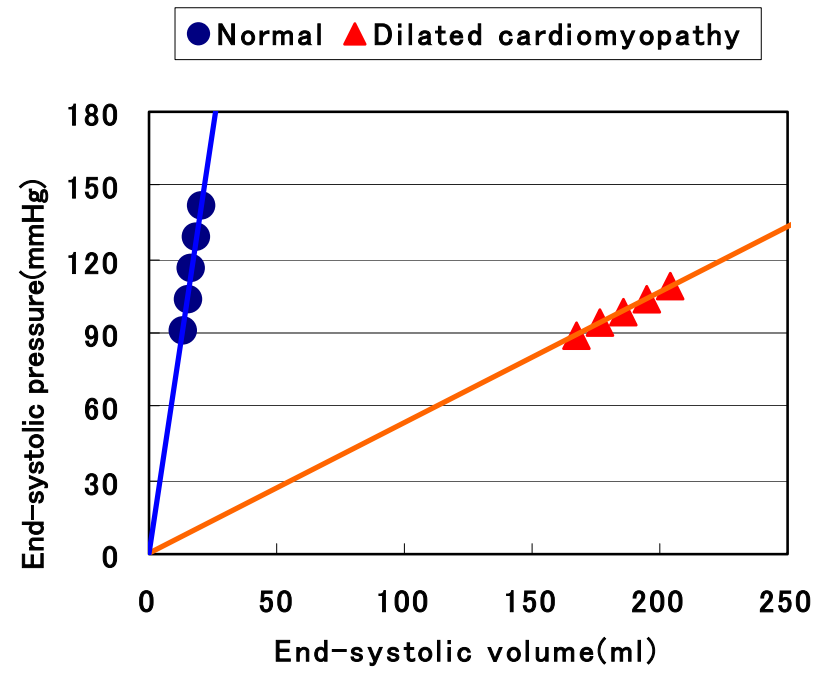

図 6 収縮末期点と $E_{\text {max }}$

Fig. 6. End-systolic points and $E_{\max }$.

- Normal $\triangle$ Dilated cardiomyopathy

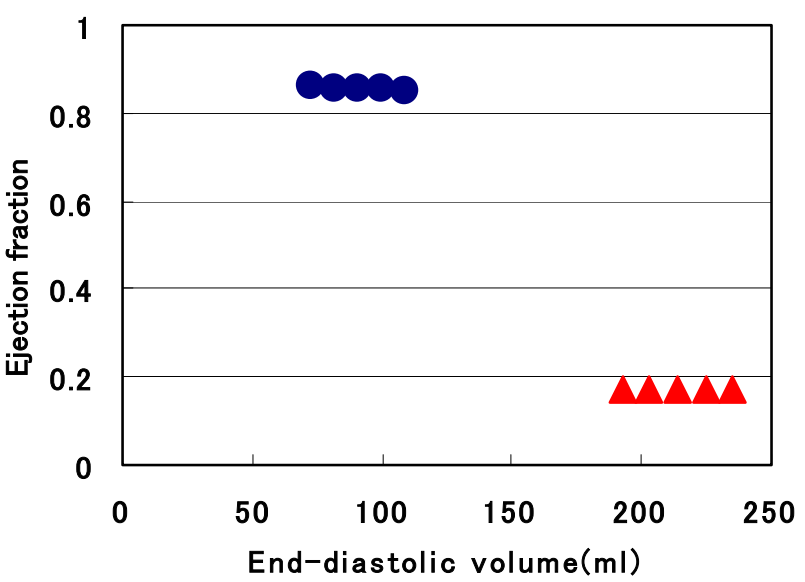

図 7 駆出率-拡張末期容積

Fig. 7. Ejection fraction - End-diastolic volume.

特徵を得ることができた。これは拡張型心笳症は心室容積 が大きく $V_{e d}$ の影響が少ないためである。

これより, 本モデルを用いて前負荷を変化させることに より $E_{\max }$ を求め心収縮機能の評価を行えることが示せた。

〈3.3〉左心室駆出率 $E F$ 図 5 の結果より, 左心室 駆出率と拡張末期容積の関係を図 7 に示す。

図 7 より, 健常及び拡張型心筋症ともに, 負荷の変化に よらずEF がほぼ一定に保たれており, Frank-Starling の法 則(17)に基づいた調節機能が働いていることが示された。

\section{4. あとがき}

血液循環全体を考慮した簡単な循環系の集中回路モデル を提案した。従来モデルでは, 部分的な表現にとどまり血 液循環全体を考慮することができず，また全体を考慮した 
モデルでは素子数が多く解析が困難であった。しかし本モ デルを用いることで血液循環全体を考慮し，

Frank-Starling の法則に基づいた調節機能による心収縮機 能の解析・評価を行えることが示せた。

心収縮機能の解析・評価を行う際に，血液循環全体を考慮 すれば各部位への影響を観察することもできる。また，症 例に関わらず同じ回路モデルを用いる事ができ，パラメー 夕值の違いのみで様々な症例の血液循環の状態を模擬する 事ができることも示した。

本論文では，健常者・拡張型心筋症患者のデータを用いて 解析を行った結果, 健常では前負荷の増加に伴った収縮末 期圧の上昇が診られ，また左心室駆出率も正常範囲であっ た。これに対し拡張型心筋症では，前負荷の増加に伴う収 縮末期圧の上昇はほとんど診られず，また左心室駆出率も 健常に比べて低く，心収縮機能の低下が示せた。今後は心 収縮性に異常をもつ他の症例についても解析を行い, 収縮 末期圧-容積関係や左心室駆出率，更にパラメータ值の違い について比較・検討する予定である。

\section{謝 辞}

本研究を遂行するにあたり，データの提供並びに有益な 御助言をいただきました京都府立医科大学附属病院の東秋 弘先生に深く感謝の意を表します。

(平成 14 年 7 月 8 日受付, 平成 15 年 8 月 8 日再受付)

\section{文献}

（1）宇都宮敏男：生体の制御情報システム，朝倉書店，pp.46-74 (1981)

(2) 阪本捷房·若林 勳: 医用電子·生体工学概論, コロナ社, pp.431-433 (1967)

(3) L.Donato, et al. : "Quantitative radiocardiography, I . Theoretical consideration”, Circulation, 26, pp.174-182 (1962)

(4) L.Donato, et al. : "Quantitative radiocardiography , II .Technics and analysis of curves", Circulation, 26, pp.183-188 (1962)

( 5 ) G.Shoroff, J.Janick, T.Weber, Am.J.Physiol., Vol.245, p.110 (1983)

(6) G.Elzinger and N.Westerhoff : Circulation Research, Vol.32, p.178 (1973)

(7) H.Suga and K.Sagawa : Circulation Research, Vol.46, p.256 (1980)

（8）村松 準: 循環の生理 第2 版, 医学書院, pp.1-53 (1989)

（9）堀川宗之：医・生物学系のための電気・電子回路，コロナ社, pp.125-127 (1997)
（10）ガイトン著, 内薗耕二・入来正躬監訳: 「人体生理学:正常機能と疾患 のメカニズム」廣川書店, pp.141-153, 179-206 (1976)

（11）金井 寛:「生体物性(2)-電気特性」, 医用電子と生体工学, Vol.13, pp.49-57 (1975)

（12）織田敏次 - 他: 内科セミナーCV1 心力学・血流循環計測法, 永井書 店, pp.343-347 (1979)

（13） L.V.アトキンソン・P.J.ハーリ・J.D.ハドソン : 数值解析計算とその 応用-FORTRAN77-, サイエンス社, pp.279-303, pp.317-324 (1995)

（14）本郷利憲・他 : 標準生理学 第 4 版, 医学書院, pp.487-497 (1996)

（15）松崎益徳：心臟病診療プラクティス 3 心機能を知る, 文光堂, pp.13-41, 167-177 (1994)

（16）菅 弘之·他: 心臟力学とエナジェンティクス, コロナ社, pp.110-126 (2000)

（17） Arthur C.Guyton, John E.Hall 著，早川弘一監訳：ガイトン臨床 生理学, 医学書院, pp.113-125, 171-188 (1999)

伊 藤 満 代 （学生員） 1978 年 4 月 24 日生。 2001 年 3 月

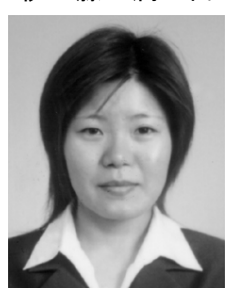
立命館大学理工学部電気電子工学科卒業。同年 4 月同大学大学院博士前期課程入学。現在, 生 体システムに関する研究に従事。電子情報通信 学会学生員。

小矢 美 晴 （正員） 1973 年 11 月 13 日生。 1997 年 3 月立

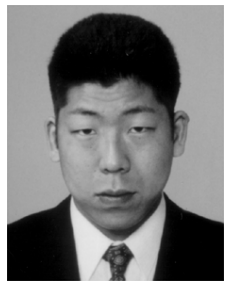
命館大学理工学部電気・電子工学科卒業。1999 年 3 月同大学大学院博士課程前期課程修了。 2002 年 3 月同大学大学院博士課程後期課程修 了。同年 4 月立命館大学理工学部助手。現在, 医用画像処理に関寸る研究に従事。工学博士。 2001 年度電子・情報・システム部門大会奨励賞 受賞。電子情報通信学会, 日本超音波医学会, ME 学会, IEEE 会員。
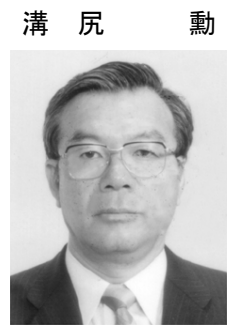

（正員） 1941 年 10 月 6 日生。 1965 年大阪府 立大学工学部電子卒業。同年三洋電機(株)入社。 1972 年大阪府立大学大学院博士課程修了。の ち, 福井大学講師, 助教授を経て, 現在, 立命 館大学理工学部教授。電子回路, 画像処理, 生 体システムに関する研究に従事。工学博士。電 子情報通信学会, ME 学会, IEEE 会員 